\title{
Quantification of Maillard reaction products in animal feed
}

\author{
Thomas Hofmann $^{1}$ D $\cdot$ Anne Christin Engling ${ }^{1} \cdot$ Siriwan Martens ${ }^{2} \cdot$ Olaf Steinhöfel $^{2} \cdot$ Thomas Henle $^{1}$
}

Received: 11 September 2019 / Revised: 26 October 2019 / Accepted: 2 November 2019 / Published online: 16 November 2019

(c) The Author(s) 2019

\begin{abstract}
Individual Maillard reaction products (MRPs), namely furosine, which is formed from Amadori product of lysine during acid hydrolysis, as well as $N$ - $\varepsilon$-(carboxymethyl)lysine (CML), pyrraline and the arginine derivative MG-H1 (methylglyoxal-derived hydroimidazolone 1) were quantified in 78 samples of animal feed, belonging to 17 different feed types. The concentrations of the MRPs were dependent on the heat treatment during processing. Within similar feed types, significant differences in concentrations could be observed. MRPs can be suitable indicators to evaluate the impact of technological processing on the nutritional quality of animal feed.
\end{abstract}

Keywords Maillard reaction $\cdot$ Glycation $\cdot$ Cattle feed $\cdot$ Pyrraline $\cdot N$ - $\varepsilon$-(carboxymethyl)lysine (CML) $\cdot$ Methylglyoxalderived hydroimidazolone 1 (MG-H1) · Furosine

\section{Introduction}

Heat treatment during processing is applied to preserve animal feed, but also to improve the digestibility of feed components in general. Among the chemical reactions occurring during heat treatment, the Maillard reaction (also referred to as "glycation") between amino compounds and reducing carbohydrates is of outstanding importance [1]. With respect to animal feed, conclusions concerning the impact of the Maillard reaction on the final product are mainly based on parameters such as "reactive lysine" [2] or digestibility [3, 4]. At present, however, there is merely a small amount of information available about the amount of individual glycation compounds in various animal feeds [5-7]. Our laboratory recently has found considerable variations in the amount of free MRPs in commercial milk, most probably due to the nutritional uptake of glycated proteins during feeding of cows [7]. Feed which was exposed to the Maillard reaction is often described as "heat-damaged" [3] and as nutritionally unavailable [8]. However, recent studies have shown that

Thomas Hofmann

thomas.hofmann4@tu-dresden.de

1 Chair of Food Chemistry, Technische Universität Dresden, 01062 Dresden, Germany

2 Department for Animal Husbandry and Feeding, Saxon State Office for Environment, Agriculture and Geology, 04886 Köllitsch, Germany microorganisms are able to utilize certain MRPs $[9,10]$. It is, therefore, conceivable that the Maillard reaction does not always have to be regarded as protein damaging. To obtain an overview about the extent of the Maillard reaction and to draw conclusions concerning an impact of processing on the nutritional value, the MRPs $N$ - $\varepsilon$-2-furoylmethyl-L-lysine (furosine), which is formed from Amadori product of lysine during acid hydrolysis, as well as $N$ - $\varepsilon$-(carboxymethyl)lysine (CML), 2-amino-6-(2-formyl-5-hydroxymethyl-1-pyrrolyl)hexanoic acid (pyrraline) and the arginine derivative $N-\delta$ (5-hydro-5-methyl-4-imidazolon-2-yl)-ornithine (MG-H1) were quantified in samples of animal feed for the first time.

\section{Materials and methods}

\section{Samples of animal feed}

A total of 78 samples of 17 different feedstuffs from ten different precursor materials, including alfalfa, sugar beet, corn, barley, pea, stillage (wheat), rapeseed, grass and mixture of grass and sugar beet, were analysed (see Table 1). These samples of feedstuffs were provided by the educational and research farm of the department for animal husbandry and feeding (Saxon State Office for Environment, Agriculture and Geology). 


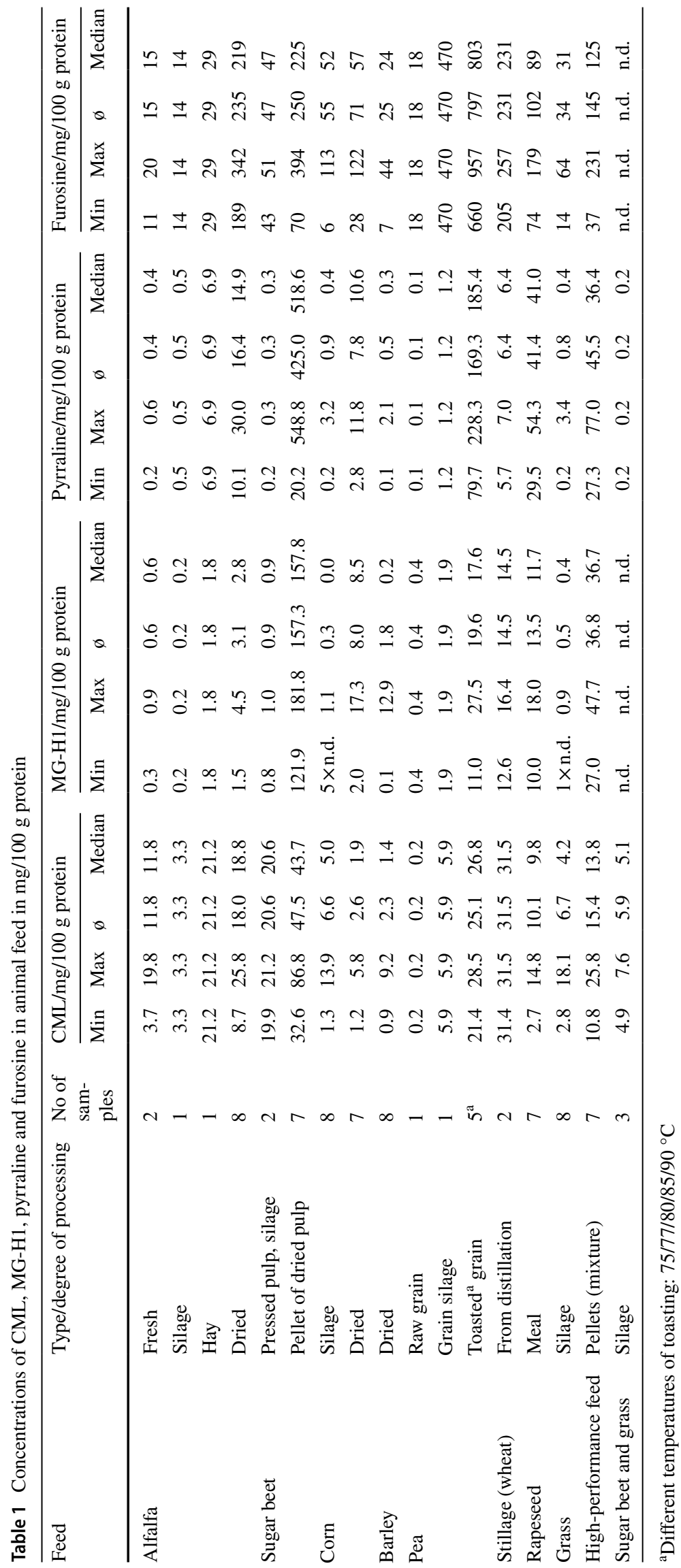




\section{Reagents}

LC-MS grade methanol and acetonitrile were obtained from Fisher Chemical (Loughborough, UK). Pepsin, pronase E, sulfuric acid and creatinine were from Merck (Darmstadt, Germany), and CML and $\left[{ }^{2} \mathrm{H}_{2}\right] \mathrm{CML}$ were obtained from PolyPeptide Group (Strasbourg, France). 2-Amino2-(hydroxymethyl)propane-1, 1-diole-hydrochloride (TRIS-HCl) was purchased from Serva Feinbiochemica (Heidelberg, Germany). Nonafluoropentanoic acid (NFPA), hydrochloric acid, prolidase, leucine aminopeptidase and $n$-heptane were from Sigma-Aldrich (Seelze, Germany). Lithium citrate buffer, lithium citrate/borate buffer, lithium hydroxide and ninhydrin were purchased from Sykam (Fürstenfeldbruck, Germany). Wieninger's catalyst was obtained from Honeywell (Seelze, Germany). Boric acid was purchased from Carl Roth (Karlsruhe, Germany) and sodium hydroxide from Grüssing (Filsum, Germany). Water was distilled (twice) before analysis.

Pyrraline [11] and MG-H1 [12] were synthesized according to the specified literature. The synthesis of $\left[{ }^{13} \mathrm{C}_{6},{ }^{15} \mathrm{~N}_{2}\right]$ pyrraline and $\left[{ }^{13} \mathrm{C}_{6}\right] \mathrm{MG}-\mathrm{H} 1$ was performed in the same manner but using $\left[{ }^{13} \mathrm{C}_{6},{ }^{15} \mathrm{~N}_{2}\right]$ lysine (pyrraline) and $\left[{ }^{13} \mathrm{C}_{6}\right]$ arginine (MG-H1) instead of the unlabeled amino acids.

\section{Analysis of MRPs}

The MRPs CML, MG-H1 and pyrraline were analysed after enzymatic digestion via LC-MS according to the literature [7]. Furosine was quantified after acid hydrolysis with $6 \mathrm{~N}$ $\mathrm{HCl}$ as reported in literature [13] with separation at a cation exchange resin column and post-column derivatization with ninhydrin [14]. All measurements were performed in duplicates.

\section{Analysis of crude protein content}

The total protein content was determined by Kjeldahl method [15] using Wieninger's catalyst. For the calculation of the protein content, the factor 6.25 was used.

\section{Results and discussion}

\section{Overview on Maillard reaction products in animal feed}

Overall, 78 samples of 17 different feedstuffs from ten different precursor materials were analysed for CML, MG-H1, pyrraline and furosine. The concentrations of these MRPs are shown in Table 1.

For fresh and humid (silage) feed samples (according to Table 1), low concentrations of MG-H1 and pyrraline were quantified, with pyrraline ranging from not detectable (below $0.03 \mathrm{mg} / 100 \mathrm{~g}$ protein) up to $1.2 \mathrm{mg} / 100 \mathrm{~g}$ protein and MG-H1 up to $1.9 \mathrm{mg} / 100 \mathrm{~g}$ protein (both in pea silage). In these feedstuffs, furosine was determined in higher concentration, ranging from not quantifiable (below $3 \mathrm{mg} / 100 \mathrm{~g}$ protein) up to $470 \mathrm{mg} / 100 \mathrm{~g}$ protein (pea silage). Furthermore, CML was found in relatively high quantities up to $21 \mathrm{mg} / 100 \mathrm{~g}$ protein (silage of sugar beet pulp).

The drying of feed at mild temperatures (e.g. in the case of dried alfalfa or dried corn) has a small effect on the concentrations of MG-H1 and pyrraline (MG-H1 up to $17 \mathrm{mg} / 100 \mathrm{~g}$ protein in dried corn and pyrraline up to $30 \mathrm{mg} / 100 \mathrm{~g}$ protein in dried alfalfa). The concentrations of furosine in dried feed varied between $7 \mathrm{mg} / 100 \mathrm{~g}$ protein (dried barley) and $342 \mathrm{mg} / 100 \mathrm{~g}$ protein (dried alfalfa), and the concentrations of CML ranged between $0.9 \mathrm{mg} / 100 \mathrm{~g}$ protein (dried barley) and $26 \mathrm{mg} / 100 \mathrm{~g}$ protein (dried alfalfa).

In comparison to the fresh and slightly processed feed (silage), a high content of CML (up to $86 \mathrm{mg} / 100 \mathrm{~g}$ protein in dried sugar beet pulp), MG-H1 (up to $182 \mathrm{mg} / 100 \mathrm{~g}$ protein in dried sugar beet pulp), pyrraline $(549 \mathrm{mg} / 100 \mathrm{~g}$ protein in dried sugar beet pulp) and furosine (up to $957 \mathrm{mg} / 100 \mathrm{~g}$ protein in toasted peas) could be quantified in highly heated (toasted) and/or pelletized feeds.

It should be noted that the concentrations of the MRPs varied widely between different samples of the same type of feed. For example, in pelletized sugar beet pulp, the amount of CML was between 33 and $87 \mathrm{mg} / 100 \mathrm{~g}$ protein, MG-H1 between 122 and $182 \mathrm{mg} / 100 \mathrm{~g}$ protein, pyrraline between 22 and $549 \mathrm{mg} / 100 \mathrm{~g}$ protein and furosine ranged from 70 to $394 \mathrm{mg} / 100 \mathrm{~g}$ protein. In addition, it is important to mention that the analysis of individual MRPs (e.g. CML or furosine) is not sufficient to estimate the blockage of amino acids such as lysine in different feeds, because the concentrations of individual MRPs do not correlate with each other. Each feed should be considered individually with regard to the blockage of different amino acids during processing.

\section{Conclusions}

The investigation showed that humid and minimally processed animal feeds contain lower concentrations of MRPs than highly processed feeds. The daily intake of MRPs can differ greatly depending on the feed used. In addition, it was observed that the concentrations of the individual MRPs can also vary considerably within the same feed types and therefore an individual evaluation of the intake of MRPs must be made for individual feedstuffs and cannot apply to processing degree of feed (e.g. fresh feed, silage, dried feed, pelletized feed). Furthermore, it was found that a determination of a particular MRP is not sufficient to assess the 
modification of proteins. An analysis of different MRPs is recommended for a more accurate evaluation of the protein modification via the Maillard reaction. However, the concentrations in animal feed are similar to the concentrations in food so the daily intake of MRPs via feed might be substantially higher (due to the daily feed intake) than the intake calculated for humans [16].

Investigations from Schwarzenbolz et al. indicated that certain MRPs can be resorbed in the digestive tract of cattle [7]. The bioavailability of the MRPs analysed in the feed (also depending on the individual feed) and whether or to what extent resorption occurs in the digestive tract of cattle needs to be examined in further studies. In addition, it should be investigated if a (partial) degradation of the MRPs might occur during the intestinal passage (e.g. during ruminal digestion) and if MRPs can be utilized by the microbiota in the digestive tract of cattle.

Acknowledgements Parts of this study were funded by European Social Fund.

\section{Compliance with ethical standards}

Conflict of interest The authors declare that they have no conflict of interest.

Compliance with ethics requirements This article does not contain any studies with human or animal subjects.

Open Access This article is distributed under the terms of the Creative Commons Attribution 4.0 International License (http://creativeco mmons.org/licenses/by/4.0/), which permits unrestricted use, distribution, and reproduction in any medium, provided you give appropriate credit to the original author(s) and the source, provide a link to the Creative Commons license, and indicate if changes were made.

\section{References}

1. Hellwig M, Henle T (2014) Baking, ageing, diabetes: a short history of the Maillard reaction. Angew Chem Int Ed Engl 53:10316-10329

2. Carpenter KJ (1960) The estimation of the available lysine in animal-protein foods. Biochem J 77:604-610

3. Goering HK, Gordon CH, Hemken RW, Waldo DR, Van Soest PJ, Smith LW (1972) Analytical estimates of nitrogen digestibility in heat damaged forages. J Dairy Sci 55:1275-1280
4. van Soest PJ, Mason VC (1991) The influence of the Maillard reaction upon the nutritive value of fibrous feeds. Anim Feed Sci Technol 32:45-53

5. Chiang GH (1983) A simple and rapid high-performance liquid chromatographic procedure for determination of furosine, a lysinereducing sugar derivative. J Agric Food Chem 31:1373-1374

6. van Rooijen C, Bosch G, van der Poel AFB, Wierenga PA, Alexander L, Hendriks WH (2014) Quantitation of Maillard reaction products in commercially available pet foods. J Agric Food Chem 62:8883-8891

7. Schwarzenbolz U, Hofmann T, Sparmann N, Henle T (2016) Free Maillard reaction products in milk reflect nutritional intake of glycated proteins and can be used to distinguish "organic" and "conventionally" produced milk. J Agric Food Chem 64:5071-5078

8. van Rooijen C, Bosch G, van der Poel AFB, Wierenga PA, Alexander L, Hendriks WH (2013) The Maillard reaction and pet food processing: effects on nutritive value and pet health. Nutr Res Rev $26: 130-148$

9. Hellwig M, Bunzel D, Huch M, Franz CMAP, Kulling SE, Henle $\mathrm{T}$ (2015) Stability of individual Maillard reaction products in the presence of the human colonic microbiota. J Agric Food Chem 63:6723-6730

10. Hellwig M, Auerbach C, Müller N, Samuel P, Kammann S, Beer F, Gunzer F, Henle T (2019) Metabolization of the advanced glycation end product $N$ - $\varepsilon$-carboxymethyllysine (CML) by different probiotic E. coli strains. J Agric Food Chem 67:1963-1972

11. Hellwig M, Geissler S, Peto A, Knütter I, Brandsch M, Henle T (2009) Transport of free and peptide-bound pyrraline at intestinal and renal epithelial cells. J Agric Food Chem 57:6474-6480

12. Hellwig M, Geissler S, Matthes R, Peto A, Silow C, Brandsch M, Henlt T (2011) Transport of free and peptide-bound glycated amino acids: synthesis, transepithelial flux at Caco-2 cell monolayers, and interaction with apical membrane transport proteins. ChemBioChem 12:1270-1279

13. Krause R, Knoll K, Henle T (2003) Studies on the formation of furosine and pyridosine during acid hydrolysis of different Amadori products of lysine. Eur Food Res Technol 216:277-283

14. Henle T, Walter H, Krause I, Klostermeyer H (1991) Efficient determination of individual Maillard compounds in heat-treated milk products by amino acid analysis. Int Dairy J 1:125-135

15. Commission regulation (EC) No $152 / 2009$ of 27 January laying down the methods of sampling and analysis for the official control of feed (OJ L 54, 26 Feb 2009)

16. Henle T (2003) AGEs in foods: do they play a role in uremia? Kidney Int 63:145-147

Publisher's Note Springer Nature remains neutral with regard to jurisdictional claims in published maps and institutional affiliations. 